\title{
Risks of Social Communications of Public Administrative Bodies with Regard to Manifestations of Corruption
}

\author{
Anatolii N. Balashov ${ }^{1 *}$ \\ Andrii M. Lyseiuk ${ }^{2}$ \\ Ivan I. Bashta 3 \\ Anastasiia D. Shtelmashenko ${ }^{4}$ \\ Andrii V. Mykoliuk4 \\ ${ }^{1}$ Professor, Department of Public Administration and Administration, \\ Interregional Academy of Personnel Management (MAUP), Kyiv, Ukraine \\ ${ }^{2}$ Deputy Head of Department for Criminal Intelligence and Surveillance Operations, \\ University of the State Fiscal Service of Ukraine, Irpin, Ukraine \\ 3 Professor, Department for Criminal Intelligence and Surveillance Operations, \\ University of the State Fiscal Service of Ukraine, Irpin, Ukraine \\ ${ }^{4}$ Assistant, Public Management and Administration Department, Faculty of Philosophy, \\ Taras Shevchenko National University of Kyiv, Kyiv, Ukraine \\ ${ }^{*}$ Corresponding Author
}

DOI: https://doi.org/10.36941/ajis-2020-0128

\section{Abstract}

The article has analyzed reasons and the current state of corruption risks in the system of social communications of public administrative bodies. The aim of the study is to identify and analyze corruption risks in the system of public communication to eliminate the causes and terms of their emerging. The article is of an overview nature, and it is prepared based on the approach of the content analysis of scientific literature on the topic, analytical reports of international organizations, international projects, the authors' analysis of sites and information portals of public authorities, and vectors of public information policy. A significant potential of corruption to destroy the trust in public institutions has been emphasized. This process will tend to weaken the state's ability to fight against corruption. By using the methodological approach "agent - patron" (agent's dilemma), it has been proved that a substantial increase in corruption processes causes considerable changes in the institutional design of public organizations. It is transforming the nature of the entire public administration system in the direction far from the public interest. This state of affairs demands the scientific community to develop theoretical and practical works offering a modern approach to the problem of countering corruption and, in particular, its institutional forms and mechanisms. The dynamics of corruption connections and relations distort the institutional design in the system of public administration, destroying effective social communications, decreasing a general level of citizens' trust in power structures, contributing to the concentration offinancial and economic assets in a very limited part of the society. The developed e-government has a great potential for countering corruption threats in general, provided the high level of information and communication competency of public authorities, and the developed information competency of citizens. Generalization of the work will be useful for public authorities during implementation processes of the comprehensive system of activities directed at prevention and fighting against corruption and planning while anti-corruption reform implementation, delivery of legal, social, economic, organizational, managerial, and practical activities aiming at corruption prevention through improvement and the further development of social communication in the public sector.

Keywords: public administration, corruption, social communications in the public sector, information office, transparency of government 


\section{Introduction}

Public administration is institutional arrangements, management practice, and institutionalized values, which officials determine legally, while the policy implementation (Henry, 1975). The state administration is a part of public administration, one of the tasks of which is to fulfill the goals of the government (Marume, 2016).

Theorists consider public administration as a means for carrying out functions and operations of the executive branch. In its turn, the executive branch should be a part of the state, public corporations, local authorities, and other institutions of the specialized nature (Henry, 1975). Thus, public administration consists of all those operations that have the implementation or implementation of public policy as their purpose (Henry, 1975). Informing the public about public policy is rather important for its effectiveness.

In the system of public administration, organizational and communicative aspects are equally important (Waldo, 1968). Nowadays expectations of citizens living in democratic countries regarding information on the state's activity, which should be accessible, have changed greatly (Huque \& Lee, 2014). Due to information technologies, social communications are developing and improving; however, at the same time, they have great potential for supporting legitimacy and contributing to the fulfillment of functions by the public authorities.

In today's world, public administrators can hardly justify the need for limited access to certain information (Semenets-Orlova et al., 2019). Social communications in the public sector include both the exchange of general information with citizens and the provision of administrative services of informational character. Citizens feel the need to demand more information to create their objective understanding of the content of a "black box" of the political process. Thus, the important problem is the improvement of social communications in the public sector through the analysis of communication risks. In modern consolidating democracies, providing further development of opacity and transparency of government, citizens see a bigger risk in their impossibility to have access to the information than in the possibility to use the information for dangerous purposes. Therefore, the objective of the study is to analyze current theoretical works in the field of risk management of social communications in public authorities in terms of corruption manifestation and the implementation to confirm generalizations some empirical data.

Until now, a set of Ukrainian and foreign developments on problems of institutional corruption and determination of mechanisms and technologies for fighting against this phenomenon in modern societies has been done. A significant character of these studies enables researchers to conduct a certain systematization of these theoretical and application-oriented works.

The first group of such scientific works is dedicated to the main types of corruption regarded in terms of their non-compliance with legal norms as well as problems of the society suffering from corruption offenses. First, in this context, works on the study of corruption as an institutional phenomenon should be mentioned (Bourdieu, 1993; Huntington, 1995). They influence the process of political decisions making and the state's policy formation (Baumgartner \& Jones, 2002; Grey, 2014; Jones \& Baumgartner, 2012).

The second group of the studies represents the analysis of organizational, legal and regulatory features of corruption as a phenomenon based on a wide array of empirical information as well as statistical and analytical data (Borshhevskiy, 2017; Nisnevich, 2014; Semenets-Orlova et al., 2019) or an empirical component of the theory of public administration (Mikhaylova, 2017; Mikhailova \& Skorobogatova, 2019; Nisnevich, 2014; Sheverdyaev, 2017; Solovyev, 2019; Solovyov, 2019; Sørensen \& Torfing, 2005). A number of modern studies on corruption, which by their subject area should be mostly classified under a regulatory element of the theory of public administration and include scientists' thoughts about corruption based on the methodology of normativism (Glinkina, 2010; Nisnevich, 2014; Solovyev, 2019; Solovyov, 2019).

However, despite a large number of works on problems of corruption that have a significant amount of information on the nature, essence, and mechanisms of countering this phenomenon, it 
should be noted that the study of social communications of the public authorities regarding manifestations of corruption (in particular, in the form of a network shadow cooperation of public actors and public law institutions) has not been studied comprehensively yet. Thus, in our point of view, the necessity to continue the study by implementing those cognitive tools that can provide deeper understanding of sources, forms, and dynamics of corruption potential of social communications of the public authorities and the appropriate mechanisms of state and administrative decision-making is methodologically valuable.

\section{Materials and Methods}

Achieving the goal outlined in the research requires analyzing the modern state and potential of social communications development in the public sector by implementing the method of theoretical generalization and comparison, as well as the method of structural and functional analysis. Using methods of collecting and analyzing statistical data, an attempt to assess the potential of corruption manifestations in the public sector has been made. The principles listed below have become the most essential for the work: (1) in the public sector, it is easier to protect from risks taken statistically and in the form of a rationally forecasted phenomenon than from risks that appear suddenly and have a complex-structured problematic character; (2) risks taken voluntarily can be easier prevented than those of "coercive nature" (including risks on the normative basis); (3) outcomes gained from the analysis of all risks should be considered as the basis for the communication campaign; also, they are to be aligned with the relevant social context.

The assessment methodology of public information policy used in the research is aimed at considering the positions of all interested parties and participants of the process. Thus, the communicative approaches of public authorities played not the least role in the process of analysis. The task of public policy is the maximum implementation of programs, which have horizontal character. So, the study used such methods as "cut-across evaluation" and "cluster-evaluation." This enabled to characterize peculiarities and to assess the system character of social communication bodies of public authorities. Based on the analysis conducted, corruption risks of such communication were identified. In addition to the methods provided above, the study used the method of scenarios analysis with the help of which possible corruption scenarios were built and analyzed for understanding in detail and studying potential corruption acts. The analysis of information systems on which the systematic character of communication in the social sphere was analyzed is used to identify possible corruption acts of an official.

\section{Results}

The institutional culture of public administration was historically a system of protection from corruption; and efforts needed to prevent manifestations of corruption, which are under control of the public administration, often determined the subject area for civil servants consolidations, and measures for popularization of their professional integrity (Whitton, 2001). According to the classical approach, corruption is a form of an unethical or dishonest behavior of a person who has authority to benefit personally. It is often discussed as a direct "creation" of the Public Service Institute (Morris, 1991) and a result of the low level of required professional ethics of a public employee needed for serving the public interests objectively and faithfully (in the system "agent - principal," where an agent is a public employee, and a principal is the entire society).

The following corruption risks in the sphere of social communication of public authorities can be provided:

1) general complexity of the procedure for the exchange of information "a state - a citizen;"

2) an unjustified long time for obtaining a certain type of public information;

3) a lack of information on procedures of obtaining a certain type of public information;

4) possible limited access to public authorities providing services (limited working hours, 
visitors standing in queues, etc.).

According to M. Sartor, each type of corruption in the body of public authorities significantly affects the organizational structure of establishments and organizations submitted to this body (Sartor, 2019).

In a public sector, corruption occurs when officials misbehave and misuse public authorities to pursue and meet their personal interests (the stated above corresponds to the logic of "an agent's dilemma" as a part of the theory of transactional expenses in the theoretical works of neoinstitutionalism). This practice is regarded as one of the most improper and unprofessional. It challenges public trust and cannot be restored without building a reputation of dignity and faithfulness. Corrupt employees are operating guided by the practice of making biased decisions, which serve to their private interests and not to the governmental ones. As a result, taxpayers are suffering because they have to bear additional cost to overcome problems of the social system caused by corrupt actions of public servants. In such type of public administration, which is weakly focused on a client (the entire society and its public (general) interest), resources, which have to be redistributed for a productive implementation, are, instead, devoted to the corrupt practice. Corruption leads to ineffective state policy in spheres and "defects that are spreading fast" in the public administration system (Stapenhurst \& Kpundeh, 1998).

Despite the fact that corruption has many reasons, the public authorities' poor arrangement is considered as the main one. The authoritarian nature of officials' behavior is strengthened by the sophistication and vagueness of ambiguous laws and resolutions. Then, eventually, it leads to the high risk that certain officials are going to make their own arbitrary decisions. Thus, the quantity of official's exclusive responsibilities is the key impact factor on corruption. A certain level of corruption practices is presented in various countries. A little less corruption practices are observed in highly regulated economies, a little more - in transit countries and countries with transition economy (Stapenhurst \& Kpundeh, 1998).

The absence of responsibility and transparency raises corruption. It is almost impossible to assess the decisions' legality if a certain group of people makes them secretly (Mills, 2012). Researchers introduced a term 'clientelism' to define the process of getting something in the society lost in corruption. In addition, the scientific world has introduced another title of this phenomenon, namely a model of patron-client policy, which has become a part of all modern political systems. This policy represents a complex set of personal relations between political philanthropists and their followers or clients. Also, this connection is based on the mutual material benefits: when patrons provide accomplices and those who depend on them with privileged resources, including money and workplaces, in exchange for assistance and collaboration. As a rule, modern clientelism flourishes in dangerous political and economic terms, and it is an integral part of a survival policy of both patrons and clients. It is a stable control mechanism in the society, which is identified in all times and terms. In such a circle "a client" asks a political patron for service; the latter is seeking to comply with the request to guarantee reelection; an administrator who has been recommended for the post by a political patron fulfills the request, and the legality of the last is not crucial for the loyalty demonstrated to the "employer."

By contrast, it is crucial to indicate the main cause of corruption, namely nepotism, which allows low-skilled, incompetent specialists to come to power to fulfill specialized tasks of professionals. Nepotism is the main driver of conflict of interest (Mills, 2012).

Low salaries in the public service encourage officials to resort to corruption to supplement their income; and because the responsibilities of public servants are not clearly defined, the incentive to take bribes outweighs the desire to build a long career in the public service. For civil servants, it is tempting to use general resources or collective benefits, because penalties for it are also not clearly defined (Mills, 2012). The private interest of a public servant can greatly differ from interests of an establishment / organization. Conflict of interests decreases public trust and confidence in the integrity and impartiality of government officials. Irrelevant policy and practice how to work with public service human resources (HR) contribute aggressively to breaches of practices that threatens transparency, 
ethical behavior and professionalism (Finlay, 2016).

In the age of the information society, communication technologies are changing the process of communication in the public sector and helping to provide social services through a computer communication network. An effective means of communication between the government and society is the e-government system, which ensures openness and transparency of government at all levels, simplifies the procedure of obtaining services, and increases the level of public confidence in the government.

In Ukraine, since the introduction of e-services for citizens, which Ukrainians have begun to actively use in recent years, in the ranking of e-government development, which is compiled by the United Nations (2018), Ukraine has risen from 87th to 62nd place, and in the ranking of e-participation - from 75th to 32nd place.

However, the process of introducing e-government in Ukraine has a number of problems.

The official source of relevant information (social communications) for community residents is the availability of updated and well-structured content sites meeting the information needs of people on public services or tools for cooperation with the government.

As a result of a social survey on the use of information and communication technologies during working with the community, only $9 \%$ of respondents rated their level as high, $11 \%$ of respondents indicated an average level of knowledge when answering the question "How do you assess your level of information and communication competence?" (United Nations, 2018). The level of respondents $(80 \%)$ who indicated a low level of ignorance and inability to use new information technologies was extremely high (Figure 1). Regarding the appropriateness of using Internet technologies and in what areas to build effective work with the community, the answers of the respondents are presented in Figure 2.

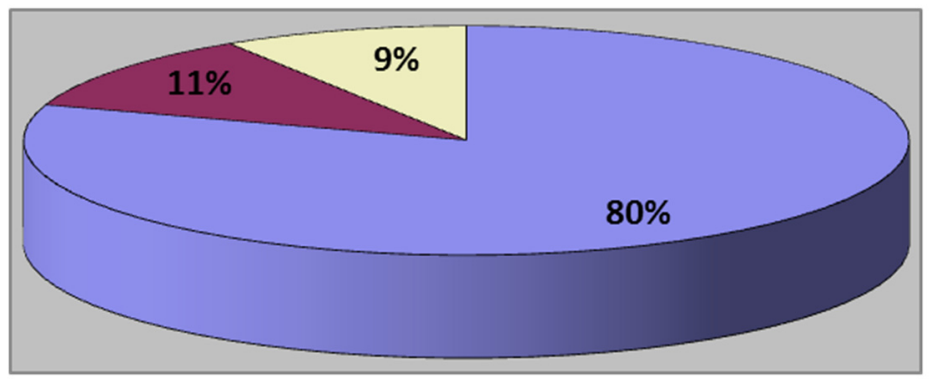

\section{$\square$ High $\square$ Average $\square$ Low}

Figure 1. Intensity levels of information and communication competency (United Nations, 2018)

It should be noted that in the context of constant updating of information and communication technologies it is difficult to get used to a huge flow of information for each citizen, without having new skills of work with information. Therefore, in the process of the modern information society formation, the practical application of information and communication technologies and information competence of public servants should be crucial, because only a specialist involved in the processes of social changes happening in the society can increase the efficiency of public service structures operation. 


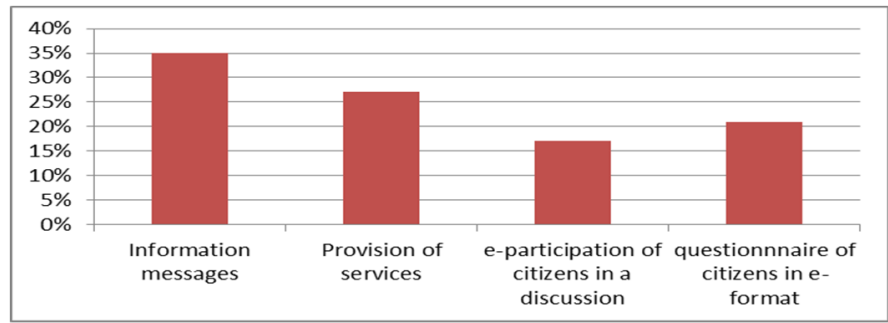

Figure 2. Areas of Internet technologies implementation (United Nations, 2018)

The analysis of statements during sociological researches provided an opportunity to identify the main topics of interest for respondents regarding their professional development in the sphere of information technology implementation in professional activities, which, at the same time, would help prevent corruption risks (Table 1 ).

Table 1. Titles of topics in the field of information technology implementation (Ukrainian Internet Association, 2019)

\begin{tabular}{|l|c|}
\hline A title of a topic & Indicator, $\%$ \\
\hline The search for the information in the Internet & 23.6 \\
\hline Work with e-mails & 12.7 \\
\hline Work with e-services of authorities & 12.3 \\
\hline E-flow of documentation & 19.5 \\
\hline Digital signature & 12.1 \\
\hline Safety while working in the Internet & 8 \\
\hline Development and filling a webpage & 6 \\
\hline E-government procurements & 5.8 \\
\hline
\end{tabular}

If in European countries people of all ages use the Internet, in Ukraine, the most active Internet users are people aged fromi 8 to 44 . It creates a gap between citizens over 55, who use the Internet less (and this remains to be a certain corruption threat). At the same time, in 2019, there is an increase in the Internet audience of users aged 55 and over (Ukrainian Internet Association, 2019) compared to 2017 (Figure 3).

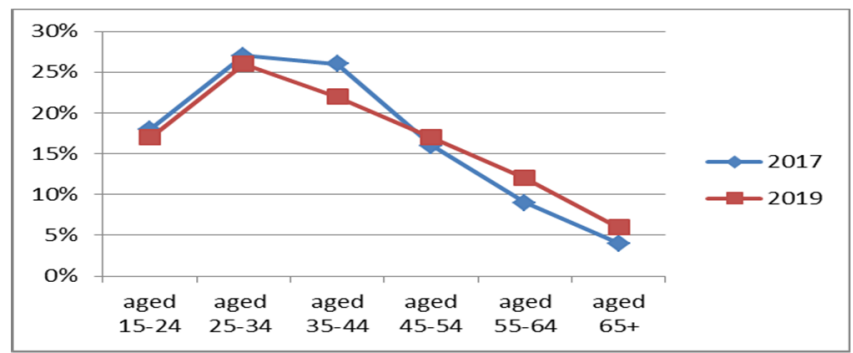

Figure 3. The demographic structure of "regular" Internet users (Ukrainian Internet Association, 2019)

To solve the problem of preventing corruption risks in the system of social communications, the continuity of national reform processes related to a greater level of government transparency and continuous training, self-improvement, and development of professional (civic) competencies of public servants themselves are equally important. The two factors stated above create a significant synergetic effect by uniting simultaneously. For example, according to the results of Sweden-Ukrainian project 
"Development of civil competencies in Ukraine - DOCCU" (DOCCU, 2018), the efficiency of training which lasted only a year and was organized for employees and servants of local authorities within the educational project on the topic of democratic citizenship and human rights strengthened by an active process of decentralization reform has shown significant results (Table 2).

Table 2. Identification of factors hindering the effective cooperation of government bodies and the public at the local level by civil servants and officials (DOCCU, 2018)

\begin{tabular}{|l|l|}
\hline 2017 & 2018 \\
\hline Lack of mutual trust and attention $-31.5 \%$ & Lack of mutual trust and attention $-18.6 \%$ \\
\hline Inactive public participation $-38.4 \%$ & Inactive public participation $-12.8 \%$ \\
\hline The unpreparedness of the authorities $-17.8 \%$ & The unpreparedness of authorities $-\mathbf{1 1 . 6} \%$ \\
\hline $\begin{array}{l}\text { Lack of proper level of integrity of the authorities }- \\
\mathbf{1 5 . 1} \%\end{array}$ & $\begin{array}{l}\text { Lack of proper level of integrity of the authorities - } \\
5.8 \%\end{array}$ \\
\hline
\end{tabular}

The results prove the significant progress of the project in terms of increasing the institutional capacity of public authorities in line with the concept of Good Governance, namely the growth of openness and transparency of authorities. This, in turn, had positive impact on the public activity at the local level, growing interest of public organizations and civil society institutions to cooperate with the authorities, in particular at the local level, and increasing the effectiveness of such cooperation. Two processes stated above jointly serve as important safeguards against manifestations of corruption in the social communications of public authorities.

Among other results of the DOCCU project mentioned earlier are in particular the following ones: the number of civil servants and local government officials increased from $30.1 \%$ to $37.2 \%$. They are observed in institutions and organizations, which nature of internal communications is characterized by open communication not constrained by orders given by the top, and the head is always seeking to listen to the opinions of his/her colleagues, to find an approach to each of them, stimulating the productive activities of each employee, and giving the sense and significance to professional activities. The number of civil servants and local government officials with an understanding of the idea of how to support the sustainable development of civil society and systematic work with the public through advanced training of public authorities has increased from $32.9 \%$ to $46.5 \%$ (Figure 4 and 5 ).

The number of civil servants and local government officials increased from $31.5 \%$ to $39.5 \%$ in the communities where opportunities have been created for active participation (communication) of local residents in the decision-making process by public authorities. The number of CSs and LGOs who have a feedback from citizens on the quality of public services provided by their institution has increased from $52.1 \%$ to $76.7 \%$. (DOCCU, 2018)

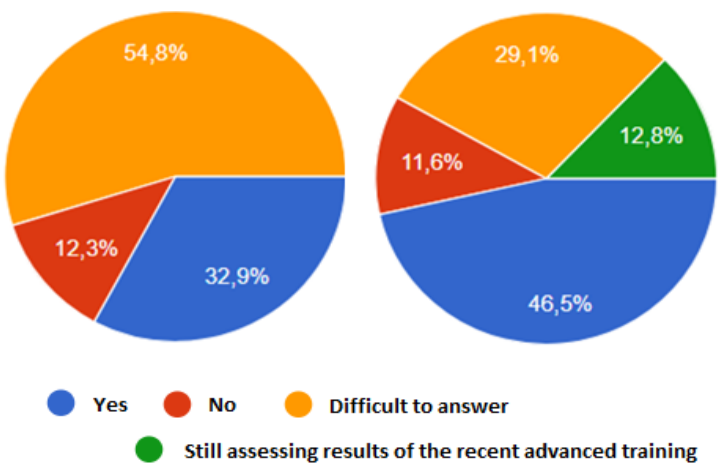

Figure 4. Understanding the importance of advanced training of SC and LGO to promote the development of civil society in 2017 and 2018 (DOCCU, 2018) 

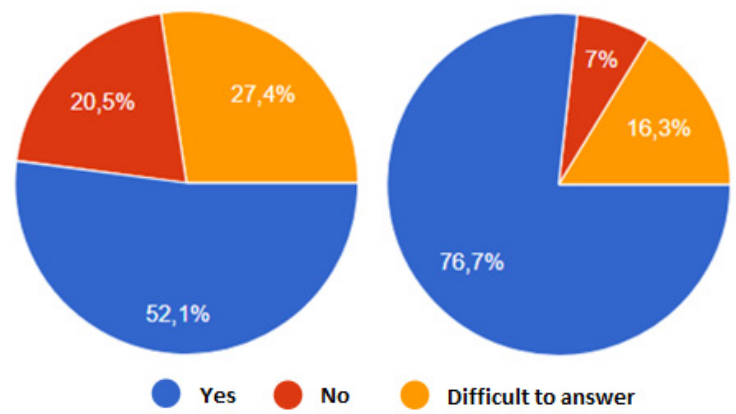

Figure 5. The state of feedback from civil servants and local government officials on the quality of public services provided to citizens (DOCCU, 2018)

\section{Discussion}

Perhaps the most significant development in the provision of social communications at the beginning of the XXI century was the extended use of the Internet by public authorities as a means of communication between the public and officials. In most European countries, the focal point for social communications of public authorities is the central information office. As for 2000, all European governments already had an official website, and almost all ministries and key agencies had their own websites.

At the same time, such a tendency has put new challenges to the systems of public administration:

1) it is necessary to actively direct efforts to overcome a "digital break" (a problem of providing wide access to the Internet in insufficiently economically active regions of countries);

2) to improve the training system, the system of employees' advanced training on information support (for example, include web design modules to programs of their training), to ensure modern equipment for specialists from information services and others.

Through the communication process the state is seeking to establish close relations with a citizen; by "imagining him/her by the side" and starting a dialogue, the state observes personal demands and complaints.

The development of corruption connections directly identifies modern relations between power bodies and business structures, strengthens the role of informal communication during making particularly key state decisions, promotes the growth of dysfunctions and even re-profiling of a number of management structures. Such phenomena even the re-profiling of a number of management structures. Such phenomena qualitatively expand the sphere of latent relations between officials and representatives (including international ones) of business, displacing various forms of civil and institutional control beyond management decisions. Combined with the costs of representative mechanisms and selectivity of justice, this situation encourages the development of patron-client relations, reduces the administrative and political responsibility of management staff, and minimizes the value of meritocratic principles of recruitment.

Nowadays, certain modern researchers believe that New Public Management is the procedure during which large bureaucratic establishments are divided into small indivisible entities. Such a process serves as a stimulus for competition between public and private organizations. Besides, it is a trigger for competition between state establishments and private companies with the implementation of economic stimuli (Dunleavy et al., 2006). The effective analysis of communication risks, as well as action tactics in situations of uncertainty, is an integral, often neglected part of public sector activity (Smith \& Mccloskey, 1998).

For the first time, the study of the risks of social communications (including those of corruption 
nature) was identified and classified as a certain scientific issue in 1969. In the 1980s, a group of scientists introduced a new vision of the notion 'risk communication,' which considered the latter in relation to their threat to destroy traditional social relations and practices. The very definition of "risk" varies depending on the "user." Researchers define risk as "the possibility of an adverse outcome and uncertainty about the terms or scale of that adverse outcome" (Covello \& Merkhofer, 1995). Theorists usually define risk as the nature of the harm causing, which can occur taking into account the number of people for whom it will have the impact. Most citizens, by contrast, are concerned with common characteristics and qualitative features, such as the origin of risk (natural or technological one) and the possibility to control it (Sandman, 1987). An inappropriate approach to risk assessment can be an obstacle for communication, including a number of corruption threats.

Can we regard corruption as a logical sequence of a human establishment? This question has provoked many debates. Consequently, it will be opened to future generations. From a liberal point of view, the activities of the state must be subject to careful control and accountability. Dysfunctions are accompanied by tension, and their consequences include hostility, low yields, stress, absenteeism, frustration, aggression, fear, dissatisfaction, and indignation at the activities of the representatives of such a state - public servants. The latter is responsible for effective communication between citizens and the state. In addition, they are regarded as a kind of link in this process. To maintain high efficiency of operation, top and personnel managers must monitor the symptoms of dysfunctions that occur in public organizations and influence them from the beginning. Symptoms of dysfunction are usually attributed to an authoritarian or incompetent management body, which maintains a monopoly of only one position through its activities, and does not allow disagreements, fearing arrogance or uncertainty. Under such conditions, personal programs that internally influence the career promotion of public servants are biased and give the impression of unfair political compensation not related to quality indicators. In such circumstances, there will always be an inefficient use of resources allocated on the basis of power-centrism and favoritism; managers will largely work to promote themselves; the workload will be unevenly distributed (some departments of the organization are underused, and others are overloaded). The nature of incompetent "excessive" management, which hinders effective internal communication in the organization, results in slowing down the functional capacity of the organization; scattered organizational efforts that have led to inter-agency competition, cause poor communication and low productivity (Pânzaru, Constantinescu \& Dragomir, 2016). All these features lead to dysfunctional and inefficient public administration.

Corruption inside any political systems, appropriation of public resources as well as bureaucracy severity are leading to decline in public administration. The stated above also contributes to its irresponsibility, and puts it on the distance from the real people's needs as well as from the public interest (Arthur, 2018). To make democracy thrive in any countries of the world, it is necessary to develop and implement ethics into its nature and structure. The state's ethics is crucial for achievements promotion of democratic political regime. In a democracy, the government is obliged to treat everyone equally and ensure the greatest benefit for the majority of residents. A democratic government demands from its public servants to be honest and responsible. They should never be dependent on the opinions of other people. This is necessary if the government wants to operate powerfully and effectively. An appropriate government body solely can make efficient decisions and pursue government policy in general. The citizens will be assured of the integrity of the entire government only in case a public official does not abuse his/her power and does not use it in his/her own interests. Ethical offenses, as well as scandals over the morality of officials, are a threat to any government. They lead to the leveling of democratic principles, violation of the rights and freedoms of citizens, and the elimination of the main provision of law. The predominance of any wrongdoing, especially bribery and deception of citizens, leads to the fact that the power begins to concentrate in a small group of people who take all functions of control. This, in turn, leads to a violation of the idea of equality, which operates in the public life of all citizens (Radhika, 2012).

Politicians of the democratic society worry about strengthening their constituencies, and thus, they are seeking to maximize some benefits for those who support them. Public administrators in the 
field, who are tempted to gain additional benefits, negotiate with their "political masters" and indulge in corruption. The damage goes beyond the loss of misdirected resources, the level of public confidence in the state is rapidly declining.

In case citizens do not trust their government, they are becoming reluctant to pay any taxes. In addition, they do not want to obey laws. The stated above leads to the necessity to improve and broaden control systems for checking and tracking the process how people follow the law (Sundell, 2015, 95-122). The reasons for trust declining in power are as follows: weak and opaque democratic management of the country; an inadequate access to the economic services or its lack; and poor possibilities of the state. If the government allows corruption in the purchase, it can result in wasting resources (goods and services) of the country, which are rather often of poor quality. Consequently, these actions lead to the unwillingness to have any business with the government structures on the part of suppliers who want to be honest with their clients (Enste \& Heldman, 2017). Due to corruption in public administration, the state will not be able to provide basic services, such as public order for society in any significant form. Corruption results in the inability of the state to settle key management duties, namely the state budget and the appointment of important government officials (Peters, 2015). Such actions lead to collapses in the operation of those political parties that have well-balanced programs and experience of effective social communications. The general governance context, which does not promote a high level of legitimacy, will negatively affect every political actor. governments which implement corruption in their everyday activities must invest less into their personal projects by lowering public officials' salaries. Then, these lower-level employees of the organization are more likely to seek opportunities to benefit illegally by devoting less time to ensuring the public interest. In most corrupt countries, unscrupulous politicians support investment projects not on the basis of their main economic means, but on the basis of the possibility to receive bribes. Such projects promote the decrease of economic growth level; in general, it reduces the trust level of (conscientious) investors, and thus, challenges the country's competitiveness, and reduces its GD) (Lopez-Claros, 2014).

Besides, it increases the level of inequality in the country which can lead to social tensions and instability. The decline in the quality of state services due to corruption results in the inefficiency of the market and persuades companies to enter the shadow economy (Fritzen, Serritzlew \& Svendsen, 2014). When corruption affects political institutions and their legitimacy, the state can be less dependent on cooperation with the citizens. This causes the emergence of primitive social communication means, which questions the entire idea of democracy. As a result, the government has to use force and coercion tactics to keep political development (Myint, 2000). Income from corruption will be hardly transferred to the investment sphere and will become a factor of capital outflow.

Transparency International defines corruption as "abuse of entrusted power for personal gain." In other words, when the transparency is absent, there will not be the law that emphasizes proper public access to information; decision-makers can act without holding them accountable.

The possibility of personal communication between a citizen and an official is one of the largest corruption risks. So, the idea of "a state in a smartphone" was based not only on providing convenience for citizens, but also on minimizing personal contacts of citizens with employees. Wider use of correspondence, information technology for communication between a customer and a provider of administrative services in the public sector significantly eliminates the possibility of the extortion of illegal remuneration, the opportunity for choosing some reasons for not accepting the application is lost. Centers for the provision of administrative services, which operate on the principle of "a single window", when a citizen does not participate in internal administrative actions, also reduces the possibility of the personal contacts mentioned above. The space of such centers usually does not provide extra barriers, which simplifies the possibility of visual observation.

The general procedural complexity of many administrative services (68.9\% of respondentsentrepreneurs think that this risk is too large) takes the leading position among corruption risks in Ukraine according to the citizens (Koliushko, Tymoschuk \& Banchuk, 2009). On the example of the administrative service stated above it is seen that the majority of administrative services have many stages, which have to be overcome by a customer alone. Moreover, in doing so, the attendance of each 
administrative body is entrusted to a customer. Although with the rational organization, most of these approvals, the provision of "conclusions," and other intermediate actions should be done within the public administration without the participation of a person (Koliushko, Tymoschuk \& Banchuk, 2009).

Since 2009, in Ukraine, a number of effective innovations have been introduced to prevent corruption threats in the communication sphere (for example, simplification of the property registration procedure, increasing the transparency of the land management system). As a result, in the Doing Business ranking, Ukraine rose from the $152^{\mathrm{d}}$ place in 2012 to the $64^{\text {th }}$ in 2020 (Doing Business, 2019).

Given that in the public sector it seems impossible to achieve the absolute implementation of the "Single Window" principle, a partial reduction in the number of instances, which a consumer of an administrative service must contact, and the establishment of a clear and comprehensive list of documents required to obtain the desired administrative service in the public sector could be regarded as a positive event. After all, confusing permitting procedures put Ukraine next to the last countries on the list and discourage investment (Koliushko, Tymoschuk \& Banchuk, 2009).

\section{Conclusion}

Despite the fact that corruption has many roots, it is usually explained by the poor design of institutions - public authorities. The timely concentration of attention on the growth of dysfunctions in the activities of public institutions, the growth of latent processes, and updated technologies of civil and legal control has a significant potential for preventing corruption processes. Impossibility to assess the legitimacy of the decisions made secretly without public recognition leads to corruption emergences with a lack of responsibilities and transparency. The decrease in the quantity of contacts between a customer of public service (a citizen) and its provider (a public servant), the use of a wide network of information technologies for periodic and completed meaningful communications between public authorities and citizens are significant fighters against corruption.

The study has confirmed theses on significant progress in the sphere of institutional capacity of public authorities in line with the concept of Good Governance in Ukraine, namely the growth of openness and transparency of government bodies in the case of training and development of civil servants' civic competences, the democratization of internal communications in a public organization, improvement of control over the activities of public authorities by the public, and implementation of the decentralization reform. It, in turn, had a positive effect on the public activity at the local level, increasing interest in cooperation with public authorities, particularly, at the local level, and increasing the effectiveness of such cooperation. Two mentioned processes together serve as a considerable preventive measure for manifestations of corruption in the social communications of public authorities.

The development of effective and efficient e-government in Ukraine is possible provided that the information and competence management staff, which will be able to put the processes of interaction with the civil society and business needs at the modern level, will be formed.

\section{References}

Arthur, E. (2016). Problems and Prospects of Public Administration in Nigeria. Information Guide in Nigeria. [Online] Available: https://infoguidenigeria.com/problems-and-prospects-gricultural-mechanization/_(May 19, 2020)

Baumgartner, F.R., \& Jones, B.D. (Eds.) (2002). Policy Dynamics. Chicago, IL: Chicago University Press.

Borshhevskiy, G. (2017). Assessment of trends in civil service: Methodological issues. Public Administration Issues, $1,103-128$.

Bourdieu, P. (1993). Sociology of politics. Moscow: Socio-Logos.

Covello, V. \& Merkhofer, M. (1994). Risk Assessment Methods. New York: Plenum Press.

DOCCU. (2018). Report on sociological research of Swiss-Ukrainian educational project "Development of Citizenship Competences in Ukraine - DOCCU”. [Online] Available: https://doccu.in.ua/analitychnyi-zvit-za-rezultatamymonitorynhu-vplyvu-shveitsarsko-ukrainskoho-proektu-rozvytok-hromadianskykh-kompetentnostei-v-ukrainidoccu/ (May 17, 2020) 
Doing Business. (2019). Doing Business 2020. [Online] Available: https://www.doingbusiness.org/en/reports/globalreports/doing-business-2020 (May 19, 2020)

Dunleavy, P., Margetts, H., Bastow, S., \& Tinkler, J. (2006). New public management is dead-long live digital-era governance. Journal of public administration research and theory, 16(3), 467-494.

Enste, D., \& Heldman, C. (2017). Causes and Consequences of Corruption - An overview of Empirical Results. IWReport, No. 2/2017. Köln: Institut der deutschen Wirtschaft (IW).

Finlay, F. (2016). Politics is corrupt, public administration is corrupt, and democracy is dead. Irish Examiner. [Online] Available: http://www.irishexaminer.com/viewpoints/columnists/fergus-finlay/.html (May 17, 2020)

Fritzen, S., Serritzlew, S., \& Svendsen, G. T. (2014). Corruption, trust and their public sector consequences: Introduction to the special edition. Journal of Comparative Policy Analysis: Research and Practice, 16(2), 117120 .

Glinkina, S. P. (2010). The corruption phenomenon: a sight of the economist. Modern and Current History Journal, 4, 3-17.

Grey, M. (2014). Governing system in communication process. New York: Gravenor.

Henry, N. (1975). Paradigms of public administration. Public Administration Review, 35(4), 378-386.

Huntington, S. (1995). The future of democratic change: from expansion to consolidation. World Economy and International Relations, 10, 693-704.

Huque, A. S., \& Lee, G. O. (2014). Issues in public management: Political direction and public communication in Hong Kong. International Review of Public Administration, 6(1), 109-120.

Jones, B., \& Baumgartner, F. (2012). From here to there: punctuated equilibrium to the general punctuation thesis to a theory of government information processing. Policy Studies Journal, $40(1), 1-19$.

Koliushko, I., Tymoschuk, V., \& Banchuk, A. (2009). Corruption risks of providing administrative and supervisory services activities in Ukraine. Kyiv: Moskalenko OM FOP.

Lopez-Claros, A. (2014). Nine reasons why corruption is a destroyer of human prosperity. World Bank. [Online] Available: http://blogs.worldbank.org/futuredevelopment/nine-reasons-why-corruption-destroyer-humanprosperity. (May 19, 2020)

Marume, S. (2016). Meaning of public administration. Journal of Research in Humanities and Social Science, 4, 15-20.

Mikhailova, O. V., \& Skorobogatova, A. V. (2019). Society against corrupttion: a view through the principal-agent model. Social and Humanitarian Knowledge, 4, 156-171.

Mikhaylova, O. V. (2017). Networks as a mechanism of value transference in public administration. E-journal. Public Administration, 62, 137-155.

Mills, A. (2012). Causes of corruption in public sector institutions and its impact on development. UNPAN. [Online] Available: http://unpant.un.org/intradoc/groups/public/documents/un-dpadm/unpan.pdf (May 17, 2020)

Morris, S. (1991). Corruption and Politics in Contemporary Mexico. Tuscaloosa: University of Alabama Press.

Myint, U. (200o). Corruption: causes, consequences and cures. Asia-Pacific Development Journal, 7(2), 34-57.

Nisnevich, Yu. (2014). Conflict of interest as a potential threat of corruption. Social sciences and modernity, 3, 23-31.

Pânzaru, S., Constantinescu, L., \& Dragomir, C. (2016). Management of dysfunctions and conflicts in public administration. [Online] Available: http://www.digilibmuscel.ro/wp-content/uploads/2017/11/4_8_Management-of-dysfunctionsand-conflicts-in-public-administration.pdf (May 17, 2020)

Peters, G. (2015). State failure, governance failure and policy failure: Exploring the linkages. Public Policy and Administration, 30, 261-276.

Radhika, D. (2012). Ethics in public administration. Journal of Public Administration and Policy Research, 4(2), 23-31.

Sandman, P. (1987). Risk communication: facing public outrage. EPA Journal, 13(9), 21-22.

Sartor, M. A., \& Beamish, P. W. (2019). Private sector corruption, public sector corruption and the organizational structure of foreign subsidiaries. Journal of Business Ethics. https://doi.org/10.1007/s10551-019-04148-1.

Semenets-Orlova, I., Klochko, A., Nestulya, S., Mykhailych, O., \& Omelyanenko, V. (2019). Readiness of the education manager to provide the organizational development of institutions (based on the sociological research). Problems and Perspectives in Management, 17(3), 132-142. http://dx.doi.org/10.21511/ppm.17(3).2019.11

Sheverdyaev, S. N. (2017). Impact of anti-corruption institutions of the Russian administrative reform on the development of constitutional legislation. Law. Journal of the Higher School of Economics, 1, 20-31.

Smith, D. \& McCloskey J. (1998). Risk and crisis management in the public sector: Risk communication and the social amplification of public sector risk. Public Money \& Management, 18(4), 41-50.

Solovyev, A. I. (2019). The political "Destruction" of statehood, or the "Noah's ark" of postmodernity. Tomsk State University Journal of Philosophy, Sociology and Political Science, 50, 200-209.

Solovyov, A. I. (2019). Political agenda of the government, or why the state needs the society? POLIS. Political studies, 4, 8-25. 
Sørensen, E., \& Torfing, J. (2005). The democratic anchorage of governance networks. Scandinavian Political Studies, 28(3), 195-218. https://doi.org/10.1111/j.1467-9477.2005.00129.X

Stapenhurst, F., \& Kpundeh, S. J. (1998). Public Participation in the fight against corruption. Canadian Journal of Development Studies, 19(3), 491-508.

Sundell, A. (2015). Public administration and corruption: How to get the institutions that work. In B. Rothstein (Ed.), Göteborg Studies in Politics 142 (pp. 95-122). Göteborg: University of Gothenburg.

Ukrainian Internet Assosiation. (2019). Internet Audience Research. [Online] Available: https://inau.ua/proekty/doslidzhennya-internet-audytoriyi (May 17, 2020)

United Nations. (2018). UN E-Government Survey. [Online] Available: https://publicadministration.un.org/egovkb/enus/Data/Country-Information/id/18o-Ukraine (May 17, 2020)

Waldo, D. (1968). Public administration. The Journal of Politics, 3o(2), 443-479.

Whitton, H. (2001). Implementing effective ethics standards in government and the civil service. OECD. [Online] Available: https://www.oecd.org/mena/governance/35521740.pdf (May 17, 2020) 